\title{
The Effect of Different Sowing Densities on Yield and Yield Components of Durum Wheat (Triticum Durum L.)
}

\author{
Arzu Mutlu* \\ Akçakale Vocational High School, Faculty of Agriculture, Harran University, 63510 Şanlıurfa, Turkey, Orcid.org/0000-0001-8992-8371, amutlu@harran.edu.tr
}

(First received 23 December 2021 and in final form 18 January 2022)

(DOI: $10.31590 /$ ejosat.1040275)

ATIF/REFERENCE: Mutlu, A. (2022). The Effect of Different Sowing Densities on Yield and Yield Components of Durum Wheat (Triticum durum L.), European Journal of Science and Technology, (33), 145-153.

\begin{abstract}
This research was carried out to determine the effect of seed sown per $\mathrm{m}^{2}$ on grain yield and some yield components (number of spikes per $\mathrm{m}^{2}$, plant height, spike length, number of grains per spike, grain weight per spike) to combat the drought experienced in Turkey and many parts of the world due to global warming. The experiment was conducted in a randomized block design with 3 replications using durum wheat (Burgos) as plant material under farmer conditions in Bozova district of Şanlıurfa province in the 2018-2019 growing season. The results showed that grain yield was between $634.17 \mathrm{~kg} \mathrm{da}^{-1}\left(650 \mathrm{seeds} / \mathrm{m}^{2}\right)$ and $591.5 \mathrm{~kg} \mathrm{da}{ }^{-1}\left(850 \mathrm{seeds} / \mathrm{m}^{2}\right)$, number of spikes per $\mathrm{m}^{2} 436.67$ pieces/spike $\left(650-750 \mathrm{seeds} / \mathrm{m}^{2}\right)$ and 436.0 pieces/spike $\left(850 \mathrm{seed} / \mathrm{m}^{2}\right)$, plant height between $88.77 \mathrm{~cm}(750$ $\left.\mathrm{seed} / \mathrm{m}^{2}\right)$ and $83.23 \mathrm{~cm}\left(450 \mathrm{seed} / \mathrm{m}^{2}\right)$, spike length was between $8.0 \mathrm{~cm}\left(450 \mathrm{seed} / \mathrm{m}^{2}\right)$ and $6.7 \mathrm{~cm}\left(850 \mathrm{seed} / \mathrm{m}^{2}\right)$, number of grain per spike was between $44.36 \mathrm{seed} /$ spike $\left(450 \mathrm{seeds} / \mathrm{m}^{2}\right)$ and $37.21 \mathrm{seed} / \mathrm{spike}\left(850 \mathrm{seeds} / \mathrm{m}^{2}\right)$, and grain weight per spike was between 1.84 gr $\left(450 \mathrm{seeds} / \mathrm{m}^{2}\right)$ and $1.665 \mathrm{gr}\left(850 \mathrm{seed} / \mathrm{m}^{2}\right)$. The grain yield and yield components in both years increased until the optimum sowing density and then decreased.
\end{abstract}

Keywords: Sowing, Density, Wheat grain yield, Spike

\section{Makarnalık Buğdayda (Triticum Durum L.) Farklı Ekim Sıklığı Uygulamalarının Verim ve Verim Komponentleri Üzerine Etkisi}

$\ddot{O} z$

Bu araştırma, 2018-2019 yetiştirme sezonunda Şanlıurfa ilinin Bozova ilçesi çiftçi koşullarında makarnalık buğday çeşidi (Burgos) ile tesadüf blokları deneme desenine göre 3 tekerrürlü olarak yürütülmüştür. Dünyada ve ülkemizde oluşan küresel 1sınmadan dolayı yaşanan kuraklıkla mücadele etmek amacıyla $\mathrm{m} 2$ ye atılacak tohum miktarının tane verimi ve bazı verim unsurlarına $\left(\mathrm{m}^{2}\right.$ de başak sayısı, bitki boyu, başak uzunluğu, başakta tane sayısı, başakta tane ağırlığı) etkisini tespit etmek amacıyla yürütülmüştür. Araştırma sonuçlarına göre; tane verimi değerinin; $634.17 \mathrm{~kg} \mathrm{da}^{-1}\left(650\right.$ tohum $\left./ \mathrm{m}^{2}\right)$ ile $591.5 \mathrm{~kg} \mathrm{da}^{-1}\left(850\right.$ tohum/ $\left.\mathrm{m}^{2}\right)$, m² de başak sayısı değerinin $436.67 \mathrm{adet} /$ başak (650- 750 tohum $/ \mathrm{m} 2)$ ile 436.0 adet/ başak $(850$ tohum $/ \mathrm{m} 2)$, bitki boyu değerinin, $88.77 \mathrm{~cm}\left(750\right.$ tohum $\left./ \mathrm{m}^{2}\right) \mathrm{ile} 83.23$ $\mathrm{cm}\left(450\right.$ tohum $\left./ \mathrm{m}^{2}\right)$, başak uzunluğu değerinin $8.0 \mathrm{~cm}\left(450\right.$ tohum $\left./ \mathrm{m}^{2}\right)$ ile $6.7 \mathrm{~cm}\left(850\right.$ tohum/ $\left.\mathrm{m}^{2}\right)$, başakta tane sayıs değerinin 44.36 adet $/$ başak $\left(450\right.$ tohum $\left./ \mathrm{m}^{2}\right)$ ile 37.21 adet/başak $\left(850\right.$ tohum $\left./ \mathrm{m}^{2}\right)$, başakta tane ağırlığı değerinin $1.84 \mathrm{gr}\left(450\right.$ tohum $\left./ \mathrm{m}^{2}\right) \mathrm{ile} 1.665 \mathrm{gr}$ $\left(850\right.$ tohum $\left./ \mathrm{m}^{2}\right)$ arasında değiştiği belirlenmiştir. Her iki yılda da optimum ekim sıklığına kadar tane verimi ve verim unsurları artmış daha sora azalmıştır.

Anahtar Kelimeler: Ekim derinliği, Buğday tane verimi, Başak.

*Corresponding Author: amutlu@harran.edu.tr 


\section{Introduction}

Wheat cultivation area of Turkey in the 2020/21 production season was $3.2 \%$ of the world wheat cultivation area, and this area constituted $44 \%$ of the total sereal planted land in Turkey. The wheat cultivation area of Turkey in 2020/21 production season was 69.2 million da, yield was $287 \mathrm{~kg}$ da-1, and the production was 20.5 million tons (Anonymous 2021). Wheat is the main source of calories in many countries today, as it was in the past, due to having sufficient nutritional value for human food and animal feed, containing balanced amino acids for human nutrition, ease of transportation, storage and processing, and wide adaptation limits (Shewry, 2009). The wheat production areas in our country and the world have reached the natural limits, and the grain yield has decreased due to severe drought seasons. Therefore, the amount of production per unit area should be increased to adequately feed the increasing population. Increasing the yield obtained from per unit area can only be achieved by the use of varieties with high yielding, quality, resistant to biotic and abiotic stresses, and suitable cultivation methods.

Development of superior genotypes as well as implementing optimum breeding techniques are needed to feed our growing population, which is expected to reach 100 million in the near future (Olgun et al. 2016). High yield is closely related to many factors related to crop yield. In addition, changes in agronomic practices lead to significant changes on yield and yield components. Implementation of optimum agronomic measures is important to increase yield obtained per unit area. Sowing the seeds at appropriate density is vital for high yield. Geleta et al. (2002) and Wajid (2004) reported that sowing density is an important agronomic factor, and especially under irrigated and arid conditions has a significant effect on yield and yield components. The sowing density varies depending on the difference in genotype and environmental factors, and optimum sowing density for optimum yield should be determined depending on the climate, soil and environment (Chen et al., 2008; Thomason et al., 2010). The sowing density is an important factor effective in increasing the grain yield per unit area. The first condition for obtaining higher grain yield per unit area for any variety under certain environmental conditions is to provide appropriate plant density (Geçit, 1982). Yield components such as the number of fertile spikes per unit area, the number of grains per spike and the grain yield per spike, depending on the plant density, have a direct effect on grain yield.

Determining the optimum sowing density is important to conserve soil water due to global warming, and to reduce seed costs of producers. Kaydan and Geçit (2005) indicated that the increase in sowing density caused an increase in the grain yield per unit area and the number of fertile spikes per square meter, and a decrease in the number of grains per spike and grain yield. Sajjad et al. (2009) revealed that the number of plants and the number of tillering per $\mathrm{m} 2$ increased with the increase in planting density in Chakwal, Pakistan. Similarly, Aldemir (2014) reported that the yield increased at the optimum sowing density, while the yield decreased with increasing further sowing density.

Ogiuchi et al. (2007) determined that increasing sowing density caused an increase in the number of spikes in
Nanbukomugi bread wheat variety in Japan. They stated that grain yield and number of spike increased linearly with increasing sowing density and the highest grain yield was obtained at 350 seed/m2 sowing density. Kazan et al. (2005) applied five different sowing densities $(350,450,550,650,750$ grains $/ \mathrm{m} 2)$ in Pehlivan bread wheat at Uludag University Faculty of Agriculture Agricultural Research and Application Center. The highest grain yield (513 kgda-1) was obtained at $750 \mathrm{seed} / \mathrm{m}^{2}$ sowing density. Kayaçetin (2006) investigated the effect of sowing density (175, $300,425,550,675,800 \mathrm{seed} / \mathrm{m} 2)$ on yield of Tarm 92 barley cultivar, by using different sowing machines in Ankara conditions. They revealed that increasing sowing density cause a decrease in spike formation time and grain filling time, decrease in the number of tillers in a plant and the number of grains per spike and increase in the number of spikes per square meter.

\section{Material and Method}

The soil analyzes from the farmer field in Bozova district in 2018 and 2019 showed that the soil properties other than organic matter content were at acceptable levels for plant growth (Table 1). The layout of the experiment was randomized block design with three replicates. The experiment was conducted under farmer conditions in Bozova district of Sanliurfa during 2018/2019 and 2019/2020 growing seasons. Burgos durum wheat variety was used as the plant material.

Table 1. Properties of Soils in the Trial Area

\begin{tabular}{l|c}
\hline Properties & Value \\
\hline E.C. ${ }^{* 103 ~}(\mathrm{Ms})$ & 1.610 \\
\hline PH & 7.22 \\
\hline Lime Ratio (\%) & 33.4 \\
\hline Total P $(\mathrm{kg} / \mathrm{da})$ & 4.65 \\
\hline Total K $\left(\mathrm{kg}^{\mathrm{d}} \mathrm{da}\right)$ & 161 \\
\hline $\begin{array}{l}\text { Organic } \\
\text { Substance Ratio (\%) }\end{array}$ & 1.45 \\
\hline Cu $\left(\mathrm{mg} \mathrm{kg}{ }^{-1}\right)$ & 1.26 \\
\hline Mn $\left(\mathrm{mg} \mathrm{kg}^{-1}\right)$ & 5.59 \\
\hline Fe $\left(\mathrm{mg} \mathrm{kg}^{-1}\right)$ & 6.05 \\
\hline $\mathrm{Zn}\left(\mathrm{mg} \mathrm{kg}^{-1}\right)$ & 1.06 \\
\hline
\end{tabular}


European Journal of Science and Technology

Table 2. Important climatic values of the trial location

\begin{tabular}{|c|c|c|c|c|c|c|c|c|}
\hline \multirow[t]{2}{*}{ Months } & \multicolumn{2}{|c|}{$\begin{array}{l}\text { Average Temprature } \\
\left({ }^{\circ} \mathrm{C}\right)\end{array}$} & \multicolumn{2}{|c|}{ Max. Temprature $\left({ }^{0} \mathrm{C}\right)$} & \multicolumn{2}{|c|}{ Min. Temprature $\left({ }^{0} \mathrm{C}\right)$} & \multicolumn{2}{|c|}{$\begin{array}{l}\text { Average Precipitation } \\
\text { (mm) }\end{array}$} \\
\hline & 2018-19 & 2019-20 & 2018-19 & 2019-20 & 2018-19 & 2019-20 & 2018-19 & 2019-20 \\
\hline November & 11.8 & 13.2 & 24.5 & 23.2 & 3.5 & 5.4 & 70.3 & 9.9 \\
\hline December & 7.6 & 8.1 & 16.1 & 19.8 & -1.0 & 1.8 & 212.8 & 131.4 \\
\hline February & 7.0 & 5.7 & 16.2 & 18.2 & 0.8 & -6.8 & 94.8 & 40.7 \\
\hline March & 10.0 & 12.0 & 20.8 & 23.8 & 1.1 & 1.7 & 96.9 & 103.5 \\
\hline April & 13.3 & 15.5 & 26.4 & 27.9 & 3.7 & 5.2 & 117.3 & 75.5 \\
\hline May & 23.3 & 21.6 & 37.9 & 36.4 & 10.2 & 10.3 & 3.4 & 49.2 \\
\hline
\end{tabular}

The first and second year sowings time were December 11, 2018 and December 19, 2019, respectively. With the sowing, $6 \mathrm{~kg}$ /da P2O5and $\mathrm{N}$ were applied to the plots, and $8 \mathrm{~kg}$ da-1 pure $\mathrm{N}$ was applied as top fertilizer. Five different sowing density (300, $400,500,600$ and 700 seed $\mathrm{m} 2$ ) treatments were used in the experiment. Herbicides were used for narrow and broad-leaved weeds. The sowing was carried out manually to the lines made with a hand marker. The size of each plot was $5 \times 1.2 \mathrm{~m}$ and each plot had 6 rows. One $\mathrm{m}$ gap was left between plots and $3 \mathrm{~m}$ between blocks. The seeds were sown at a depth of 4 to $6 \mathrm{~cm}$ at $20 \mathrm{~cm}$ interrow spacing (Akkaya, 1994).

\section{Results and Discussion 3.1. Grain Yield $\left(\mathrm{kg} \mathrm{da}^{-1}\right)$}

The combined grain yield analysis indicated that the effect of year, treatment and year $\mathrm{x}$ treatment interaction $(\mathrm{P} \leq 0.01)$ had a statistically significant effect on grain yield (Table 3 ). The highest grain yield (634.17 kg da-1) was obtained at $650 \mathrm{seed} / \mathrm{m} 2$ density, while the lowest grain yield $(591.5 \mathrm{~kg}$ da-1) was obtained at 850 $\mathrm{seed} / \mathrm{m} 2$ sowing density (Table 4 ). Grain yield was lower in the second year compared to the first year due to excessive temperature and insufficient precipitation.

Table 3. Table 3. Combined variance analysis of different sowing densities applied in durum wheat on plant height, spike length, the number of grains per spike, grain weight per spike, grain yield, and number of spike per M² in 2018-2019, 2019-2020.

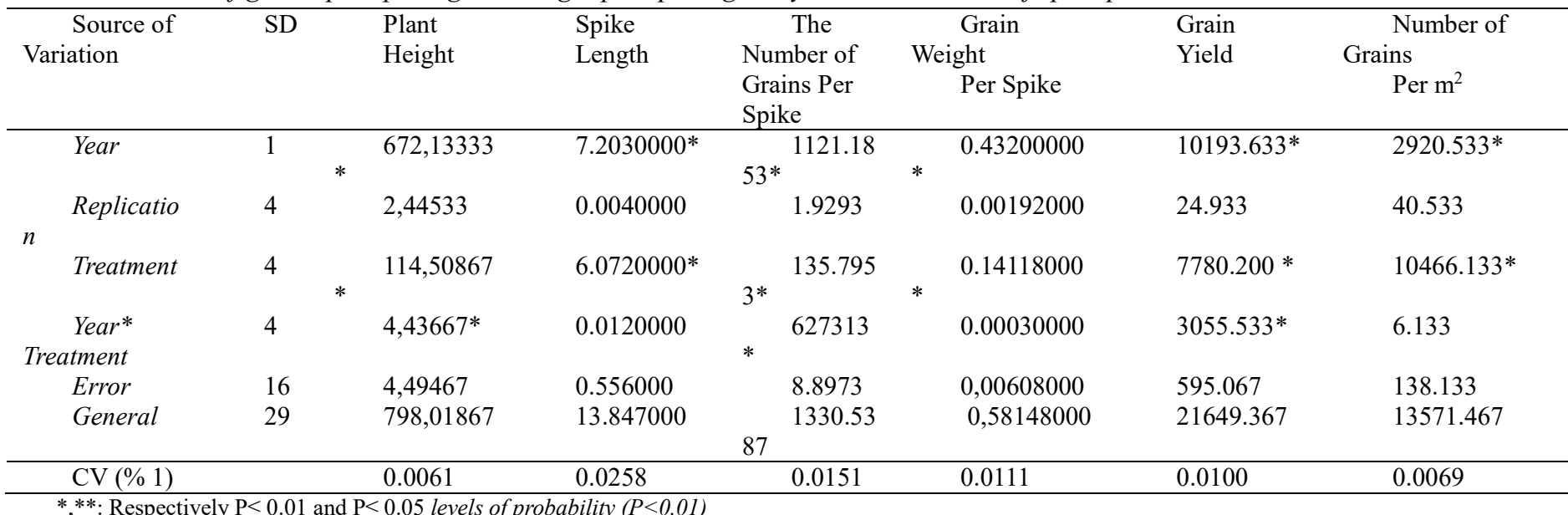


Table 4. Means and multiple comparison test results related to grain yield ( $\mathrm{kg} \mathrm{da}^{-1}$ ) of different sowing densites

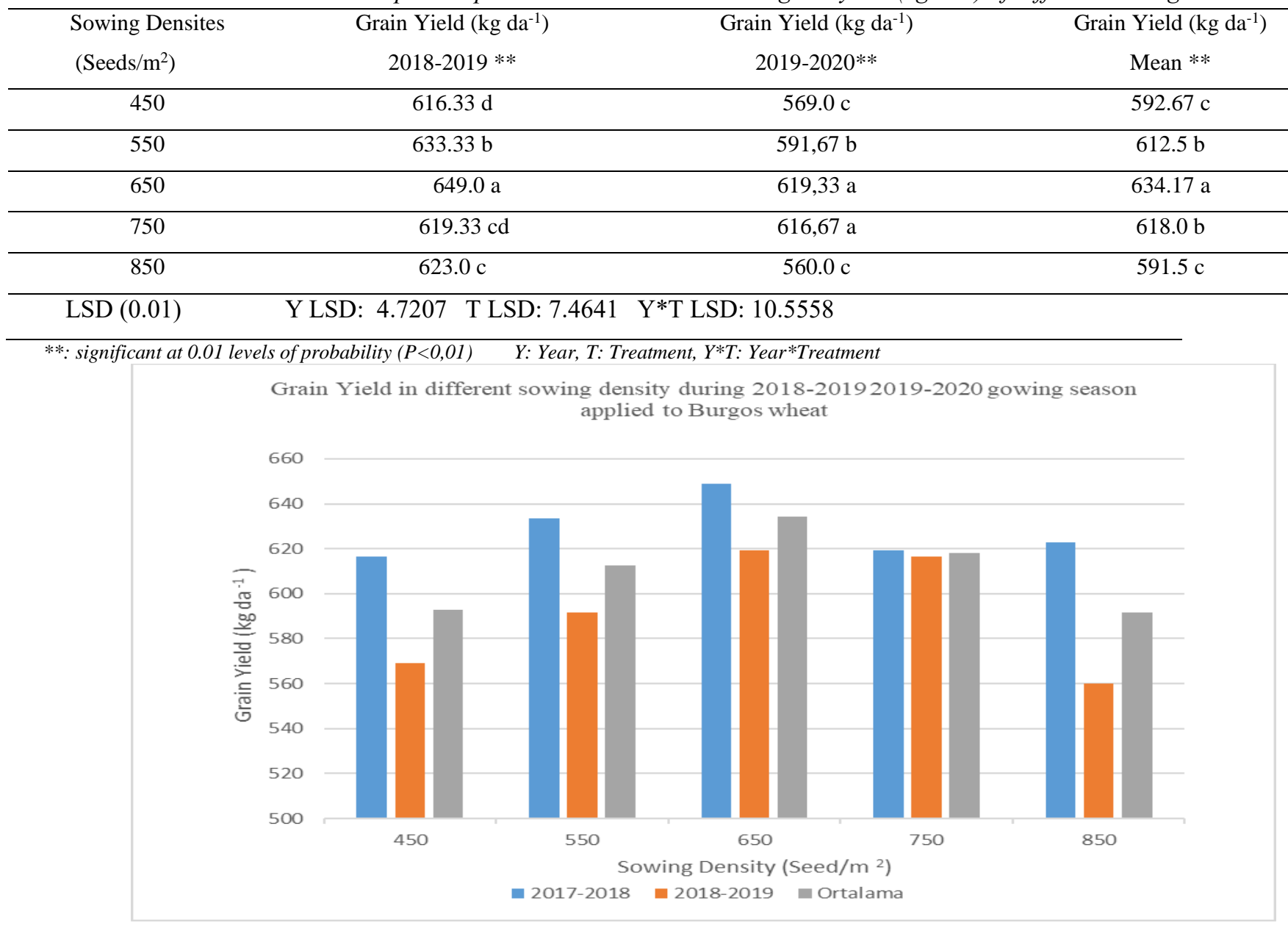

Figure 1. Grain yield in different sowing density during 2018-2019 and 2019-2020 growing seasons

The increase in sowing density cause a decrease in spike length, which also cause further decrease in the number of grains per spike and the grain size. The plants better use of soil nutrients and sunlight at the optimum planting density, and grow better. Similar to all plants, vegetative and generative development of wheat is related to the plant's use of soil water. The plants uptake water through the roots to transport nutrients from soil to upper body parts and to perform vital metabolic processes. Therefore, the need for water increases with the increase in plant density. The amount of precipitation and temperature in the first year of the experiment were higher than the second year. In dry years, available water content of soil depletes, therefore, grain yield and yield components that affect grain yield significantly decrease even if additional irrigation is applied. Parameters such as the number of spikes per plant and the number of grains per spike directly affect the grain yield per unit area, and these values vary with the plant density (Kaydan et al., 2012). The results obtained are also in agreement with the researchers who reported that grain yield increased with increasing sowing density (Kara 2007, Turk \& Tawaha 2003, Teich and Smid 1993, Kaydan 2003, Kara). Grain yield per unit area increased with the increase in planting density up to a certain rate and the highest values were reached at $650 \mathrm{seeds} / \mathrm{m}^{2}$ planting density. Many studies have reported that the highest grain yield can be obtained with the optimum sowing density in both irrigated and rainfed conditions (Iqbal et al., 2012;
Akınc1, 2014; Anwar et al., 2015). The increase in sowing density increases the dry matter accumulation following the heading stage (Fang et al 2010), however, the dry matter accumulated in the grain is adversely affected after a certain sowing density. Sowing density up to 650 seeds $/ \mathrm{m}^{2}$ increased the grain yield, while grain yield started to decrease sowing density higher than 650 seeds $/ \mathrm{m}^{2}$ (Figure 1). Similar to our findings, most of the studies conducted in different regions and with different cultivars reported that the grain yield increases up to a certain sowing density, and than decreases after that density (Kayaçetin, 2006; Çağlar et al., 2009; O'Donovan et al., 2012). The increase in sowing density causes competition among plants due to the presence of more plants per unit area, therefore, water and nutrients per plant decrease and grain yield decreases (Dai et al., 2013; Haile et al., 2013; Shah, 2016).

\subsection{Number of Spike Per $\mathrm{M}^{2}$ (number/spike)}

The combined data showed that the effect of year, treatment and year $\mathrm{x}$ treatment interaction on the number of spikes per $\mathrm{m}^{2}$ was statistically significant $(\mathrm{P} \leq 0.01)$ (Table 3$)$. The highest spike number (436.67 head/spike) per $\mathrm{m}^{2}$ was obtained with $650-750$ $\mathrm{seed} / \mathrm{m}^{2}$, while the lowest value (436.0 head/spike) was recorded with $850 \mathrm{seed} / \mathrm{m}^{2}$ sowing density (Table 5). 
Table 5. Means and multiple comparison test results related to number of grains per $m^{2}$ of different sowing densites (number/spike)

\begin{tabular}{|c|c|c|c|}
\hline $\begin{array}{l}\text { Sowing Densites } \\
\left(\text { Seeds } / \mathrm{m}^{2}\right)\end{array}$ & $\begin{array}{c}\text { Number of Grains Per } \mathrm{M}^{2} \\
\text { (number/spike) } \\
2018-2019^{* *}\end{array}$ & $\begin{array}{c}\text { Number of Grains Per } \mathrm{M}^{2} \\
\text { (number/spike) } \\
2019-2020^{* *}\end{array}$ & $\begin{array}{c}\text { Number of Grains Per } \mathrm{M}^{2} \\
\text { (number/spike) } \\
\text { Mean** }\end{array}$ \\
\hline 450 & $401,33 \mathrm{c}$ & $375 d$ & $391.3 \mathrm{~b}$ \\
\hline 550 & $419.0 \mathrm{~b}$ & $400 \mathrm{c}$ & $408.67 \mathrm{~b}$ \\
\hline 650 & $446.67 \mathrm{a}$ & $432 \mathrm{ab}$ & $436.67 \mathrm{a}$ \\
\hline 750 & $445.0 \mathrm{a}$ & $442.0 \mathrm{a}$ & $436.67 \mathrm{a}$ \\
\hline 850 & $446.67 \mathrm{a}$ & $430 \mathrm{~b}$ & $436.0 \mathrm{a}$ \\
\hline
\end{tabular}

\footnotetext{
**: significant at 0.01 levels of probability $(P<0,01) \quad Y$ : Year, T: Treatment, $Y^{*} T:$ Year ${ }^{*}$ Treatment
}

Sowing density up to 650 seeds $/ \mathrm{m} 2$ increased the number of grains per $\mathrm{m} 2$ in different sowing densities, while grain yield started to decrease sowing density higher than 650 seeds $/ \mathrm{m} 2$ (Figure 2).

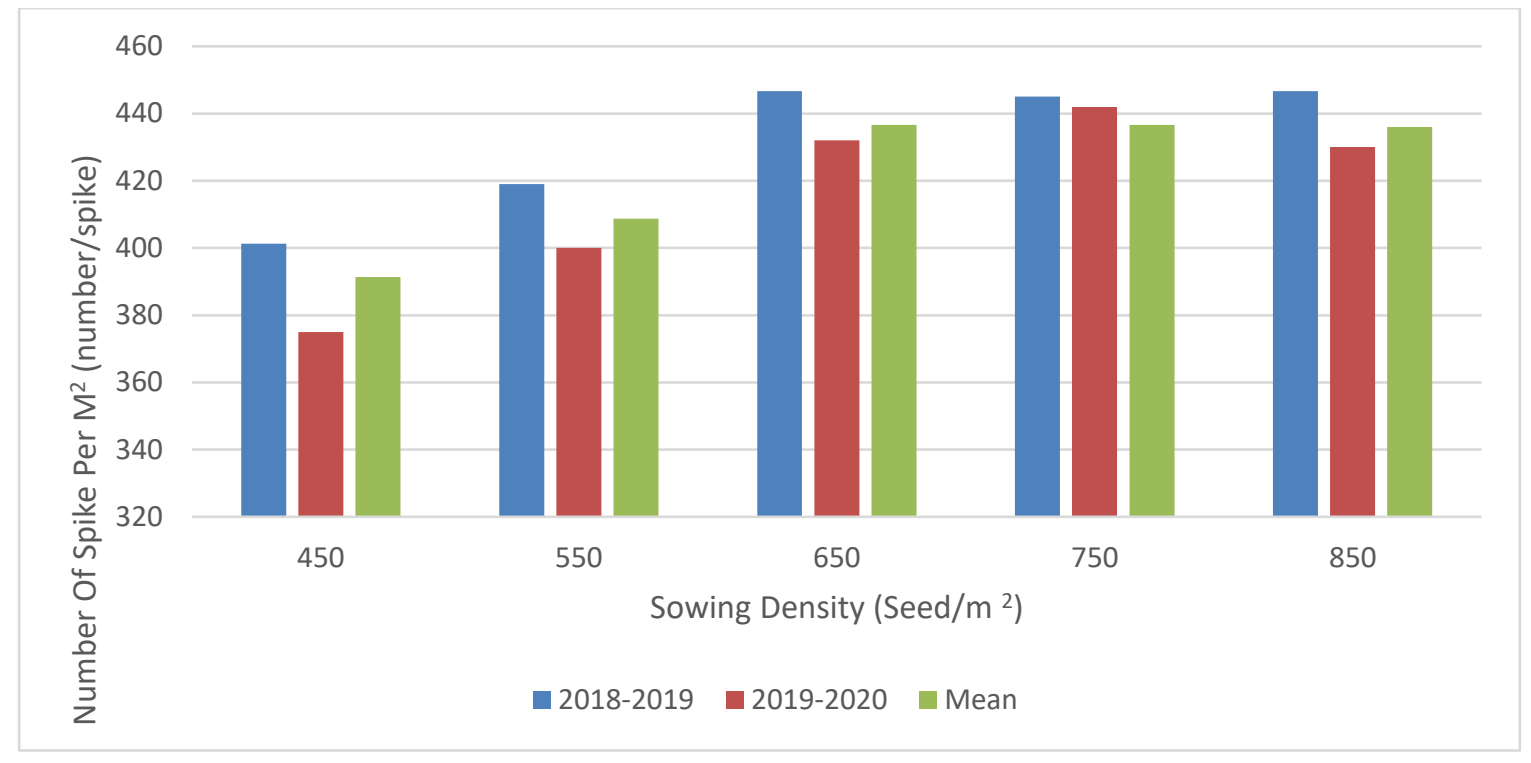

Figure 2. $\mathrm{M}^{2}$ Number of Grains Per $\mathrm{m}^{2}$ in different sowing density during 2018-2019 2019-2020 gowing season applied to Burgos wheat

The increase in sowing density up to 650 grains $/ \mathrm{m} 2$ increased the number of spikes per square meter, while the number of spike values were close to each other in subsequent sowing density treatments. The decrease in tillering with the increase in sowing density starting from the sowing density of $650 \mathrm{seeds} / \mathrm{m} 2$ caused a decrease in the number of spikes per square meter. The amount of precipitation in the second year up to the heading stage was significantly lower than the precipitation in the first year. However, precipitation during and after the heading period in the second year was considerably higher compared to the first year, and this precipitation caused to form new tillers in the postheading period and these tillers produced new spikes. Therefore, the number of spikes per $\mathrm{m} 2$ was very close in sowing densities higher than $650 \mathrm{seed} / \mathrm{m} 2$. Previous studies investigated the effects of different sowing densities indicated that sowing density significantly affects the number of spikes per square meter. (Geleta et al., 2002; Cheema et al., 2003; Thomason et al., 2010; Özdemir, 2011; Iqbal et al., 2012; Akınc1, 2014; Wood et al., 2003).

\subsection{Plant Height}

The combined data showed that the effect of year, treatment and year $\mathrm{x}$ treatment interaction on plant height was statistically significant $(\mathrm{P} \leq 0.01)$ (Table 3$)$. The highest plant height $(88.77$ $\mathrm{cm})$ per $\mathrm{m} 2$ was obtained with $750 \mathrm{seed} / \mathrm{m} 2$, while the lowest value $(83.23 \mathrm{~cm})$ was recorded with $450 \mathrm{seed} / \mathrm{m} 2$ sowing density (Table 6). 
Table 6. Means and Multiple Comparison Test Results Related To Plant Height ( $\mathrm{kg}$ da ${ }^{-1}$ ) of Different Sowing Densites

\begin{tabular}{|c|c|c|c|}
\hline Sowing Densites & Plant Height $(\mathrm{cm})$ & Plant Height $(\mathrm{cm})$ & Plant Height $(\mathrm{cm})$ \\
\hline$\left(\right.$ Seeds $\left./ \mathrm{m}^{2}\right)$ & $2018-2019 * *$ & $2019-2020^{* *}$ & Mean** \\
\hline 450 & $88.13 \mathrm{~d}$ & $78,33 \mathrm{~d}$ & $83.23 \mathrm{~d}$ \\
\hline 550 & $90.40 \mathrm{c}$ & $80.50 \mathrm{c}$ & $85.45 \mathrm{c}$ \\
\hline 650 & $91.47 \mathrm{bc}$ & $83.53 \mathrm{a}$ & $87.50 \mathrm{~b}$ \\
\hline 750 & $93.73 \mathrm{a}$ & $83.80 \mathrm{a}$ & $88.77 \mathrm{a}$ \\
\hline 850 & $92.47 \mathrm{ab}$ & $82,70 \mathrm{~b}$ & $87.58 \mathrm{~b}$ \\
\hline
\end{tabular}

\begin{tabular}{ccc}
\hline LSD $(0.01)$ & Y LSD: 0.4102 T LSD: 0.6486 & Y*T LSD: 0.9174 \\
\hline **: significant at 0.01 levels of probability $(P<0,01)$ & Y: Year, T: Treatment, $Y^{*}$ T: Year*Treatment
\end{tabular}

Plant height increased up to 750 seeds $/ \mathrm{m} 2$ sowing density and then decreased (Table 6). The leaves shade each other at high sowing density, therefore, the plants height increases to reach the light needed. However, when the sowing density exceeds the optimum sowing density, the plant height cannot increase further. In addition, the effect of water deficiency on plant height, especially in the stem elongation period, had a greater effect than the water deficiency and irregularity observed in the grain filling period. The precipitation in the second year especially when it needed was insufficient, therefore available plant water content was very low which caused plant heights to be shorter than the first year, even if additional irrigation was applied. Some researchers have also reported that plant height is significantly affected by the sowing density (Geleta et al., 2002; Khan et al.,
2002; Zeybek et al., 2005; Soomro et al., 2009; Torofder and Hossain 1991; Kaydan 2003; Wood et al. 2003). Geleta et al. (2002) reported that the plant height increased up to a certain point with the increase of sowing density and decreased with further increase in sowing density.

\subsection{Spike Length}

The combined data indicated that the effect of year, treatment and year $\mathrm{x}$ treatment interaction on plant spike length was statistically significant $(\mathrm{P} \leq 0.01)$ (Table 3$)$. The longest spike length $(8.0 \mathrm{~cm})$ was obtained with $450 \mathrm{seed} / \mathrm{m} 2$, while the shortest value $(6.7 \mathrm{~cm})$ was recorded with $850 \mathrm{seed} / \mathrm{m} 2$ sowing density (Table 7).

Table 7. Means and multiple comparison test results related to spike length (cm) in different sowing densities

\begin{tabular}{cccc}
\hline $\begin{array}{c}\text { Sowing Densites } \\
\left(\text { Seeds } / \mathrm{m}^{2}\right)\end{array}$ & $\begin{array}{c}\text { Spike length }(\mathrm{cm}) \\
2018-2019\end{array}$ & $\begin{array}{c}\text { Spike length }(\mathrm{cm}) \\
2019-2020\end{array}$ & \multicolumn{2}{c}{$\begin{array}{c}\text { Spike length }(\mathrm{cm}) \\
\text { Mean }\end{array}$} \\
\hline 450 & $8.5 \mathrm{a}$ & $7,5 \mathrm{a}$ & $8.0 \mathrm{a}$ \\
550 & $7.6 \mathrm{bc}$ & $6.66 \mathrm{bc}$ & $7.1 \mathrm{c}$ \\
650 & $7.8 \mathrm{~b}$ & $6.9 \mathrm{~b}$ & $7.35 \mathrm{~b}$ \\
750 & $7.4 \mathrm{~cd}$ & $6.4 \mathrm{c}$ & $6.9 \mathrm{~cd}$ \\
850 & $7.2 \mathrm{~d}$ & $6.2 \mathrm{c}$ & $6.7 \mathrm{~d}$ \\
\hline
\end{tabular}

LSD $(0.01) \quad$ Y LSD: 0.1443 T LSD: $0.2281 \quad$ Y*T LSD: 0.3226

**: significant at 0.01 levels of probability $(P<0,01) \quad$ Y: Year, T: Treatment, $Y^{*} T$ : Year*Treatment

Dense seed sowing caused a decrease in spike length in both years of the experiment. Nutrient, water and light per plant decrease with the increase in sowing density per unit area. The plant height decreases with the competition among plants, and also spike length decreases accordingly. The results on adverse effect of high sowing density on spike length are in accordance with those reported by Naveed et al. (2014), Adinew (2015), Gooding et al. (2002), Atak and Çiftçi (2005) and Ahmad et al. (2000).

\subsection{The Number of Grains Per Spike}

The combined data on the number of grains per spike indicated that the effect of year, treatment and year $\mathrm{x}$ treatment interaction on the number of grains per spike was statistically significant $(\mathrm{P} \leq 0.01)$ (Table 3$)$. The highest number of grains per spike .(44.36 grain/spike) was obtained with $450 \mathrm{seed} / \mathrm{m} 2$, while the lowest value (37.21 grain/spike) was recorded with 850 seed/m2 sowing density (Table 8 ).

The highest number of grains per spike in both years of the experiment was obtained in the highest sown density (450 seed $/ \mathrm{m} 2$ ), while the lowest number of grains per spike was recorded the least dense sowing $(850 \mathrm{seed} / \mathrm{m} 2)$ treatment (Table 8). The number of grains per spike is usually determined prior to the flowering period (Warrington et al., 1977). The number of grains per spike decreased linearly with the increase in the amount of seeds planted per square meter. 
Table 8. Means and Multiple Comparison Test Results Related To The Number of Grains Per Spike of Different Sowing Densites

\begin{tabular}{cccc}
\hline $\begin{array}{c}\text { Sowing Densites } \\
\left(\text { Seeds } / \mathrm{m}^{2}\right)\end{array}$ & $\begin{array}{c}\text { The Number of Grains } \\
\text { Per Spike (gr /spike) }\end{array}$ & $\begin{array}{c}\text { The Number of Grains } \\
\text { Per Spike (gr /spike) }\end{array}$ & $\begin{array}{c}\text { The Number of Grains } \\
\text { Per Spike (gr /spike) }\end{array}$ \\
\hline 450 & $48.53 \mathrm{a}$ & $40.20 \mathrm{a}$ & $44.36 \mathrm{a}$ \\
550 & $47.00 \mathrm{~b}$ & $38.10 \mathrm{~b}$ & $42.55 \mathrm{~b}$ \\
650 & $45.33 \mathrm{c}$ & $35.56 \mathrm{c}$ & $40.45 \mathrm{c}$ \\
750 & $43.66 \mathrm{~d}$ & $31.73 \mathrm{~d}$ & $37.70 \mathrm{~d}$ \\
850 & $43.46 \mathrm{~d}$ & $30.96 \mathrm{~d}$ & $37.21 \mathrm{~d}$ \\
\hline
\end{tabular}

LSD (0.01) Y LSD: 0.4729 T LSD: $0.7478 \quad$ Y*T LSD: 1.0576

**: significant at 0.01 levels of probability $(P<0,01) \quad Y$ : Year, T: Treatment, $Y^{*}$ T: Year ${ }^{*}$ Treatment

The decrease in the number of grains per spike with the increase in sowing density can be associated with the increase in the number of plants and spikes per unit area, as well as the decrease in the area where the plants benefit from water and nutrients (Kaydan et al., 2012). Increasing sowing density under both rainfed and irrigated conditions had a decreasing effect on the number of grains per spike. Similar results have been reported in many other previous studies (Rüegger et al., 1993; Öztürk, 1996; Spink et al., 2000; Chaudhry and Hussain, 2001; Hussain et al., 2001; Lloveras et al., 2004; Bokan and Malesevic, 2004; Bulut, 2009; Nakano and Morita, 2009; Soomro et al., 2009; Dinç, 2010; Kılıç and Gürsoy, 2010; Ahmadi et al., 2011; Özdemir, 2011; Haile et al., 2013; Adinew, 2015; Li et al., 2016).

\subsection{Grain Weight Per Spike}

The combined data on the grain weight per spike indicated that the effect of year, treatment and year $\mathrm{x}$ treatment interaction on the grain weight per spike was statistically significant $(\mathrm{P} \leq 0.01)$ (Table 3). The highest grain weight per spike (7.81 g) was obtained with $450 \mathrm{seed} / \mathrm{m} 2$, while the lowest value $(1.665 \mathrm{~g})$ was recorded with $850 \mathrm{seed} / \mathrm{m} 2$ sowing density (Table 8 ). The grain weight per spike decreased rapidly with the increasing sowing density, but this ratio of decrease was not high with the further increase in the sowing density.

Table 9. Means and Multiple Comparison Test Results Related To Grain Weight Per Spike (gr /spike) of Different Sowing Densites

\begin{tabular}{cccc}
\hline $\begin{array}{c}\text { Sowing Densites } \\
(\text { Seeds/m })\end{array}$ & $\begin{array}{c}\text { Grain Weight } \\
\text { Per Spike (gr/spike) }\end{array}$ & $\begin{array}{c}\text { Grain Weight } \\
\text { Per Spike (gr/spike) }\end{array}$ & $\begin{array}{c}\text { Grain Weight } \\
\text { Per Spike (gr/spike) }\end{array}$ \\
\hline 450 & $1.96 \mathrm{a}$ & $1.72 \mathrm{a}$ & $1.84 \mathrm{a}$ \\
550 & $1.92 \mathrm{a}$ & $1.68 \mathrm{~b}$ & $1.80 \mathrm{~b}$ \\
650 & $1.85 \mathrm{~b}$ & $1.61 \mathrm{c}$ & $1.73 \mathrm{c}$ \\
750 & $1.80 \mathrm{c}$ & $1.55 \mathrm{~d}$ & $1.675 \mathrm{~d}$ \\
850 & $1.78 \mathrm{c}$ & $1.55 \mathrm{~d}$ & $1.665 \mathrm{~d}$ \\
\hline
\end{tabular}

LSD $(0.01) \quad$ Y LSD: 0.0150 T LSD: $0.0238 \quad$ Y*T LSD: 0.0337

**: significant at 0.01 levels of probability $(P<0,01) \quad Y$ : Year, T: Treatment, $Y^{*} T$ : Year*Treatment

The decrease in grain weight per spike in the second year was higher than that of the first year. Grain weight per spike is determined by the number of grains per spike and the 1000-grain weight (Korkut et al. 1993), which positively affects the grain yield (Kahraman 2006). The decrease in spike length with the increase in sowing density causes a decrease in the number of grains per spike. The results may be attributed to the significant effect of hereditary traits on 1000-grain weight compared to the other yield traits and the effect of 1000-grain weight on grain weight per spike. In addition, the precipitation, especially in April and May, in the second year, caused the formation of new tillers, however, high temperature in the second year caused a shortening of the grain filling period and thus a decrease in the grain weight per spike. Previous studies indicated that high sowing densities also limit grain filling period and reduce 1000-grain weight (Kayaçetin, 2006; Çağlar et al., 2009; O’Donovan et al., 2012; (Bavec and ark., 2002; Kazan and Doğan, 2005; Laghari et al., 2011; Özdemir, 2011; Li et al., 2016).

\section{Conclusions and Recommendations}

The results revealed that grain yield and yield components of durum wheat differed significantly depending on the different sowing densities. The increasing sowing density increased the grain yield, the number of spikes per square meter, and the plant height values; while decreased the spike length, number of grains per spike and grain weight per spike. The increase in sowing density had a positive effect on plant growth, grain yield and yield components to a certain extent, but after a certain point, high sowing density adversely affected plant growth, grain yield and yield factors. The use of soil moisture at the highest level and increasing the grain yield and yield component values can only achieved by determining the most suitable sowing density. Climate change is one of the most important environmental and economic problems of our time. Therefore, the use of soil 
moisture at the maximum level will ensure to benefit from the plant nutrients in the soil and accordingly, obtain the highest yield

\section{References}

Adinew A. 2015. Effect of Seed Source and rates on productivity of Bread Wheat (Triticum aestivum L.) Varieties at Kersa, Eastern Ethiopia. A Thesis Submitted to School of Plant Sciences, School of Graduate Studies Haramaya University.

Ahmad, Z., Kisana, N. S., Mujahid, M. Y., Ahmad, I., Mustafa S. Z., Majid, A. 2000. Effect of Population Density on Yield and Yield Components of Wheat. Pakistan Journal of Biological Sciences, 3(9): 1389-1390.

Akınc1, C., Çölkesen, M., 1999. Determination of the effect of sowing time and sowing frequency on yield and yield components of durum wheat. Cereals Symposium, 658-664, Konya. (in Turkish)

Anonim 2021. Wheat, June-2021, Report for Agricultural Products, TEPGE. Pdf. (in Turkish).

Anwar, S., Khattak W.A., Inamullah, M.I., Bashir, S., Shafi, M.,2015. Effect of Sowing Dates and Seed Rates on the AgroPhysiological Traits of Wheat. Journal of Environment and Earth Science ISSN 2224-3216 (Paper) ISSN 2225-0948 (Online)Vol.5, No.1, 2015.

Atak, M., ve C.Y. Çiftçi, 2005. The effect of different planting frequencies on yield and some yield components in Triticale (Triticosecale Wittmack), Journal of Agricultural Sciences, 11(1) 98-103. (in Turkish)

Chen, C., Neill, K., Wichman, D., Westcott, M., 2008. Hard Red Spring Wheat Response to Row Spacing, Seeding Rate, and Nitrogen. Agronomy Journal, 100:1296-1302.

Çekiç C., Savaşl1, E., Dayığlu, R., Önder, O., Karaduman, Y., Avcioğlu R., 2008. Determination of the Relationship between Sowing Time and Frequency and Quality Criteria in Bread Wheat (Triticum aestivum L.). Turkey Grain Symposium, Konya. (in Turkish)

Chaudhry, A. U., Hussain, I., 2001. Influence of Seed Rate on Phenology, Yield and Quality of Wheat. Pakistan Journal of Biological Sciences, 4 (4): 414-416.

Conry,M.J and Hegarty,A.1992. Effect of sowing date and seed rate on the grain yield an protein content of winter barley. Journal of Agric. Science, 279.

Donaldson, E., Schilinger, W. F., Dofing, S. M., 2001. Straw Production and Grain Yield Relationships in Winter Wheat. Crop Sci. 41:100-106.

Holen, D. L., Bruckner, P. L., Martin, J. M., Carlson, G. R., Wichman, D. M., Berg, E. J., 2001. Small Grains. Published in Agron. J. 93:364-370.

FAO, (2018). http://www.fao.org/faostat/en/\#data/QC, Erişim, Mart, 2020.

Fang Y, Xu B, Turner N C \& Li F (2010). Grain yield, dry matter accumulation and remobilization, and root respiration in winter wheat as affected by seeding rate and root pruning. European Jornal of Agronomy 33: 257-266

Geleta, B., Atak, M., Baenziger, P. S., Nelson, L. A., Baltenesperger, D. D., Eskridge, K. M., Shipman, M. J., Shelton, D. R., 2002. Seeding Rate and Genotype Effect on Agronomic Performance and End-Use Quality of Winter Wheat. Crop Sci. 42:827-832.

Gooding, M.J., A. Pinyosinwat ve R.H. Ellis, 2002. Responses of wheat grain yield and quality to seed rate. Journal of Agricultural Sciences, 138, 317-331.
Harris, P.B.1984. The Effect of sowing date, disease control, seed rate and the application of a plant growth regulator of autumn nitrogen on the growth and yield 1gri winter barley. Research and devolopment in agriculture.

Iqbal, J., Hayat, K., Hussain, S., Ali, A., Bakhsh, M.A.A.H.A.,2012. Effect of Seeding Rates and Nitrogen Levels on Yield and Yield Components of Wheat (Triticum aestivum L.) Pakistan Journal of Nutrition 11,7 (2012):531536.

Kahraman, T (2006). Determination of the Effects of Different Sowing Time and Nitrogen Fertilization Applications on Grain Filling Time and Grain Filling Rate, Yield and Quality Factors in Some Bread Wheat Varieties. T.U. Graduate School of Natural and Applied Sciences, Unpublished Doctoral Thesis, 177. (in Turkish)

Kara, K., 2007. The Effects of Different Sowing Frequencies and Nitrogen Doses on Yield and Yield Components in Some Triticale Varieties. Ph.D. Thesis, Ankara University Institute of Science and Technology, Ankara, $92 \mathrm{p}$ (in Turkish).

Khan, H., Khan, A. M., Hussain, I., Khan, Z. M., Khattak, K. M., 2000. Effect Of Sowing Methods And Seed Rates On Grain Yield And Yield Components Of Wheat Variety Pak-81. Pakistan Journal of Biological Sciences. 3 (7): 1177-1179.

Kayaçetin F (2006). Yield and yield components of barley planted with different planting machines in Ankara conditions and applied with a roller. Çukurova University, Institute of Science and Technology, Department of Field Crops, PhD Thesis, 164s, Adana. (in Turkish)

Kaydan, D. 2003. The effects of sowing methods and sowing densities on yield and yield components in barley. Ankara Univ. Science Ins. Doctoral Thesis, 134 p., Ankara. (in Turkish)

Kaydan, D., Geçit, H.H., 2005. The Effects of Sowing Methods and Sowing Densities on Yield and Yield Components in Barley. Yüzüncü Y1l University, Faculty of Agriculture, Journal of Agricultural Sciences (J. Agric. Sci.), 15(1): 43-52.

Kaydan, D., Tepe, I., Yağmur, M. , Yergin, R., 2012. The Effects of Sowing Method and Density on Grain Yield, Some Yield Components and Weeds in Wheat. Journal of Agricultural Sciences 17 (2011): 310-323. (in Turkish)

Kazan, T., Doğan, R., 2005. A Study on Sowing Time and Sowing Density in Pehlivan Bread Wheat (T. aest. var. aest. L.). Uludag Univ. Agriculture. Fac. Journal. 19(1): 63-76. (in Turkish)

Korkut Kz, Başer İ, Bilir S (1993). Studies on Correlation and Path Coefficients in Durum Wheat. Durum Wheat and Its Products Symposium, 30 November - 03 December, 1993, Ankara, 183-187. (in Turkish)

Naveed K, Khan MA, Baloch MS, Ali K, Nadim MA. 2014. Effect of different seeding rates on yield attributes of dualpurpose wheat. Sarhad J. Agric. 30(1): 83-91.

Nakano, H., Morita., 2009. Effects of Seeding Rate and Nitrogen Application Rate on Grain Yield and Protein Content of the Bread Wheat Cultivar 'Minaminokaori' in Southwestern Japan. Plant Production Science. 12(1) : 109-115.

Ogiuchi, K., Takahashi, A., Sakuyama, K., 2004. Optimum Seeding Date and Seeding Density for Winter-Seeding Cultivation of Winter Wheat in Iwate. Japanese Journal of Crop Sciences. Vol. 73, pp.396-401.

O’Donovan JT, Turkington TK, Edney MJ, Juskiw PE, McKenzie RH, Harker KN, Clayton GW, Lafond GP, Grant CA, Brandt S, Johnson EN, May WE, Smith E (2012). Effect of seeding 
date and seeding rate on malting barley production in western Canada. Can. J. Plant Sci. 92: 321-330.

Özdemir S (2011). Determination of Optimum Sowing Frequency of Wheat Varieties Sown in Different Locations. Eskişehir Osmangazi University, Institute of Science and Technology, Department of Field Crops, Undergraduate Thesis, Eskişehir. 32 p. (in Turkish)

Öztürk, A., Akten, Ş. 1998. Sowing density and Response to Nitrogen Doses of Structures on Flag Leaf Knots in Winter Wheat. Journal of Anadolu Aegean Agricultural Research Institute, 8(1). (in Turkish)

Schillinger, F. W., 2005. Tillage Method and Sowing Rate Relations for Dryland Spring Wheat, Barley, and Oat. Published Crop Science. 45:2636-2643.

Shahzad MA, Sahi ST, Khan MM, Ahmad M. 2007. Effect of sowing dates and seed treatment on grain yield and quality of wheat. Pakistan Journal of Agricultural Sciences.

Shewry, P.R. (2009). Wheat. Journal of Experimental Botany, 60 (6), 1537-1553.

Soomro, U. A., Rahman,M. U., Odhano E. A., Gul S., Tareen, A. Q., 2009. Effects of Sowing Method and Seed Rate on Growth and Yield of Wheat (Triticum aestivum). World Journal of Agricultural Sciences. 5 (2): 159-162.

Sümer-Özcan F, Erekul O, Koca Y O (2010The effects of plant density and nitrogen doses on yield, yield components and bread quality characteristics in different wheat (Triticum aestivum L.) cultivars. Anadolu Journal of AARI 20 (2): 2844. (in Turkish)
Sümer, F. Ö., 2008. Effects of Plant Density and Nitrogen Doses on Yield, Yield Components, Agronomic and Quality Characteristics of Bread Wheat (Triticum aestivum L.) Varieties and Relationships Between Traits. Aydın Institute of Science and Technology, Ph.D. Thesis, 146 Pages, Aydın. (in Turkish)

Şehitoğlu M (2007). The Effects of Different Seed Densities on Yield, Yield Components and Quality Traits in Barley Varieties. Selcuk Univ. Institute of Science Department of Field Crops, Master Thesis, Konya. (in Turkish)

Teich, A.H., Smid, A., 1993. Seed rates for soft white winter wheat in Southwestern Ontorio. Can. J. Plant.Sci., 73 (6): 1071-1073.

Zeybek, A., Özkan, İ., Tan, E., 2005. The Effect of Different Sowing Densities and Nitrogen Doses on Yield and Yield Components of Ziyabey-98 Bread Wheat Varieties. Turkey 6th Field Crops Congress Research Presentation, Cilt1, s.105-109. (in Turkish)

Wang, D., Yu, Z., \& White, P. J., 2013, The effect of supplemental irrigation after jointing on leaf senescence and grain filling in wheat. Field Crops Research, 151, 35-44.

Wood G A, Welsh J P, Godwin R J, Taylor J C, Earl R \& Knight $S$ M (2003). Real-time measures of canopy size as a basis for spatially varying nitrogen applications to winter wheat sown at different seed rates. Biosystems Engineering 84(4): 513 531 